\title{
Berpikir Kritis Dalam Pengambilan Keputusan Pada Keperawatan
}

\author{
Nikita Gina Chesena Sembiring \\ nikitagina.ng@gmail.com
}

\section{LATAR BELAKANG}

Masyarakat sebagai pengguna layanan kesehatan lebih selektif dalam memilih tempat pelayanan. Untuk itu, rumah sakit sebagai salah satu penyedia layanan kesehatan yang dituntut harus memberi pelayanan yang berkualitas. Kualitas suatu rumah sakit sudah tentu tergantung pada kualitas pelayanan keperawatan yang diberikan oleh perawat. Karena selain perawat merupakan jumlah tenaga kesehatan yang paling banyak di rumah sakit, perawat adalah tenaga kesehatan yang paling lama berinteraksi dengan pasien dan yang paling dekat dengan pasien (Nursalam, 2014). Oleh karena itu kualitas pelayanan keperawatan merupakan suatu hal yang sangat penting untuk diperhatikan oleh pihak rumah sakit.

Bagi sebuah rumah sakit, sangat penting akan adanya perawat. Terutama perawat yang cepat tanggap dalam melayani pasien, karena perawat merupakan sumber daya rumah sakit yang paling sering berinteraksi dengan pasien. Seperti diketahui bahwa daya tanggap perawat merupakan salah satu dari lima dimensi pelayanan. Kualitas pelayanan erat kaitannya dengan proses pengambilan keputusan pasien, di mana kualitas yang baik akan memberikan pengalaman bagi pasien dan dan selanjutnya akan mengundang mereka datang kembali untuk kunjungan berikutnya.

Pengambilan keputusan adalah suatu proses penilaian dan pemilihan dari berbagai alternatif sesuai dengan kepentingan-kepentingan tertentu dengan menetapkan suatu pilihan yang dianggap paling menguntungkan (Machfoedz,2005). Menurut James A. F keputusan adalah suatu pemilihan diantara alternatif-alternatif. Sedangkan pengambilan keputusan menurut James A titik-titik Stoner pengambilan keputusan adalah proses yang dipakai untuk memilih suatu tindakan sebagai cara mengatasi suatu masalah.

Pengambilan keputusan yang baik dari Perawat akan mendukung kualitas perawatan yang diberikan kepada pasien, tetapi jika tidak didukung dengan pengetahuan dan keterampilan yang baik dari perawat dalam melakukan pengambilan keputusan klinik keperawatan maka akan menurunkan mutu dan kualitas dari proses keperawatan yang 
diberikan kepada pasien. Pembuatan keputusan klinik adalah hal yang sangat vital pada praktik keperawatan.

Poin dari pembuatan keputusan keperawatan harus memiliki dampak yang menyeluruh terhadap performa organisasi dan mampu memberikan dampak secara finansial. Memberikan kualitas dan pelayanan yang aman adalah tujuan dari seluruh organisasi pelayanan kesehatan. Oleh karena itu pembuatan keputusan klinik yang efektif harus benarbenar dilaksanakan (Diane L, 2018).

Kemampuan membuat keputusan klinik oleh perawat merupakan inti dari praktik keperawatan. Asuhan keperawatan yang diberikan oleh perawat kepada pasien menuntut perawat untuk mengambil keputusan dalam setiap tindakan dan proses keperawatan. Perawat yang tidak terampil dalam mengambil keputusan tentu akan merugikan pasien sebagai penerima perawatan. Selain fatal dan menyebabkan kematian tentunya perawat yang raguragu dalam mengambil keputusan klinik akan menyebabkan lamanya perawatan pasien akan bertambah dan biaya pun akan bertambah.

Menurut mertes, 1991 itu berpikir kritis adalah suatu proses yang sadar dan juga sengaja yang digunakan untuk dapat menafsirkan serta mengevaluasi informasi dan pengalaman dengan sejumlah sikap reflektif dan dan kemampuan yang memandu keyakinan dan tindakan. Manfaat berpikir kritis adalah mampu menyelesaikan masalah, membantu dalam pengambilan keputusan, membedakan antara fakta dan opini, dan dan membantu untuk dapat tetap tenang sekalipun dalam masalah sulit.

Setiap tindakan yang dilakukan secara rasional oleh seseorang selalu melibatkan keputusan atau pilihan. Setiap pengambilan keputusan dan penyelesaian masalah menuntut seseorang itu untuk dapat menerima hal baru, perbedaan, dan aspek-aspek yang lebih kompleks dari lingkungan yang sudah ada ada (Nursalam, 2008). Mutu asuhan keperawatan menjadi alat utama menjaga kepercayaan pelanggan pelayanan. Asuhan keperawatan bermutu dilakukan dengan meningkatkan kemampuan berpikir kritis perawat dalam melakukan proses keperawatan. Pelayanan keperawatan didasarkan pada pendekatan pengambilan keputusan yang dapat ditingkatkan dengan berpikir kritis (Ignatavicus \& Workman,2006).

Dalam pengambilan keputusan Seorang perawat harus berlandaskan etika praktik keperawatan yang berdasarkan pada pemikiran kritis dan dan efektif mengenai tanggung jawab dan kewajiban seorang perawat terhadap pasien (Jan Florin, 2007 dan Fakultas Ilmu Keperawatan Universitas Padjadjaran, 2013). Teori yang dikemukakan kan oleh Buckingham 
and Adams pengambilan keputusan klinis merupakan perilaku klasifikasi (Jan Florin, 2007). Klasifikasi dapat diartikan bahwa pengambilan keputusan merupakan sebuah pola tertentu Sama halnya dengan proses keperawatan dalam setiap proses keperawatan perawat harus mampu mengambil keputusan klinis.

\section{METODE}

Kajian ini dilakukan dengan metode menganalisis dari berbagai sumber bacaan. Baik dari berbagai jurnal online, e-book, skripsi yang memiliki hubungan dengan pengambilan keputusan dalam keperawatan.

Penulisan kajian ini melakukan metode perbandingan antar satu artikel dengan artikel lainnya. Kemudian perbandingannya ditulis secara beraturan dalam hasil dari kajian. Dengan isi yang akan dibandingkan tetap berhubungan dengan pengambilan keputusan dalam keperawatan.

\section{HASIL}

Didapat dari beberapa referensi, bahwa berpikir kritis mempengaruhi pengambilan keputusan perawat dalam asuhan keperawatan. Hubungan perawat-klien adalah dasar dari praktik keperawatan yang berfokus pada pasien. Keterlibatan pasien merupakan inti dari proses keperawatan, sehingga partisipasi pasien dalam proses keperawatan menjadi penting dalam penentuan kualitas dan efektivitas dalam pelayanan asuhan keperawatan.

Proses pengambilan keputusan merupakan komponen penting dalam proses keperawatan Diana Catarina, 2009), sehingga dibutuhkan kemampuan perawatan karena keterbatasan pengetahuan dan kemampuan yang dimiliki perawat dapat menghambat perawat dalam mengambil keputusan mengenai perawatan yang akan diberikan kepada pasien yang akan berakibat fatal terhadap pasien(Kozier et al, 2010).

Beberapa konsep yang digunakan untuk menggambarkan berpikir kritis dalam keperawatan adalah penalaran klinis, perumusan diagnostik, pengambilan keputusan, penilaian, dan pemecahan masalah. Menurut penelitian yang dilakukan oleh Panggabean 2019 kemampuan berpikir kritis perawat dalam pengambilan keputusan berhubungan erat dengan kemampuan berpikir kritis perawat dengan nilai $\mathrm{p}=0,026$ dan juga ga menurut Khairina, 2018 pengalaman kerja mempunyai hubungan erat dengan kemampuan pengambilan keputusan dengan nilai pvalue 0,012 . 
Berpikir kritis digambarkan sebagai sebuah proses tujuan untuk membuat keputusan yang masuk akal tentang apa yang harus percaya dan apa yang harus dilakukan. Pengambilan keputusan klinis adalah suatu proses yang melibatkan kedua penalaran diagnostik dan penilaian klinis. Tindakan dalam tindakan ini diarahkan sebagai proses refleksi dari perawat maupun pasien (Jan Florin, 2007).

Pengambilan keputusan sangat penting dalam asuhan keperawatan maupun dalam manajemen keperawatan. Pengambilan keputusan merupakan suatu proses yang mencakup semua penilaian kegiatan yang diperlukan guna membuktikan dan memperlihatkan pilihan terbaik dalam menyelesaikan suatu masalah tertentu. Setiap keputusan adalah akibat dari sebuah proses dinamis yang dipengaruhi oleh banyak kekuatan pengambilan keputusan bukan merupakan prosedur yang tetap akan tetapi merupakan sebuah proses yang beruntun. Pengambilan keputusan keperawatan dilakukan pada semua Tahap proses keperawatan annas orang perawat harus mampu berpikir kritis, berkomunikasi dengan baik sebagai suatu elemen penting dalam pengambilan keputusan, sehingga terjadi pembelajaran berkelanjutan bagi pasien yang dapat meningkatkan tingkat kemandirian pasien.

Suarsana dan Mahayukti 2013, keterampilan berpikir kritis adalah keterampilan mengidentifikasi fakta yang relevan, mengenali keterbatasan, asumsi-asumsi atau kekhususan yang berkaitan dengan prosedur yang digunakan, dan menentukan jawaban yang rasional. Berpikir kritis dalam keperawatan adalah untuk mengambil keputusan dan kemampuan untuk berpikir secara sistematis dan logis dengan keterbukaan terhadap pertanyaan dan merenungkan proses penalaran yang digunakan untuk memastikan keamanan praktik keperawatan dan kualitas caring (Aliyu dkk, 2014).

Berpikir kritis sangat penting membantu perawat untuk memilih solusi atau mengidentifikasi pilihan untuk situasi perawatan pasien. Perawat diwajibkan untuk berpikir kritis di semua tempat termasuk di rumah sekolah perawatan rawat jalan, unit perawatan kritis, dan pusat komunitas. Perawat harus bekerja dari basis pengetahuan yang luas yang mengindividualisasi kan perawatan untuk setiap pasien dan pengaturan. Kemampuan perawat untuk berpikir kritis akan menjadi salah satu keterampilan yang paling penting(Craven \& Hirnle, 2009)

Berpikir kritis menjadi bagian yang tak terpisahkan dari Asuhan Keperawatan yang dilakukan oleh perawat. Berpikir kritis penting dilakukan sebelum mengambil keputusan dalam asuhan keperawatan Karena berpikir kritis dalam keperawatan merupakan 
keterampilan berpikir perawat untuk menguji berbagai alasan serta rasional, sebelum mengambil keputusan dalam asuhan keperawatan (Ignatavicius \& Workman, 2006).Perawat harus mampu mengidentifikasi masalah pasien dan memilih solusi intervensi yang tepat, karena Perawat akan menghadapi bermacam macam situasi klinis yang berhubungan dengan pasien gimana hal ini tidak terlepas dari kemampuan perawat dalam berpikir kritis, karena dengan berpikir secara kritis perawat dapat mengambil keputusan secara sistematis dan tepat dalam setiap tahapan Asuhan Keperawatan yang dilakukan.

\section{PEMBAHASAN}

Keputusan dalam penyelesaian masalah adalah kemampuan mendasar bagi praktisi kesehatan, khususnya dalam asuhan keperawatan. Tidak hanya berpengaruh pada proses pengelolaan asuhan keperawatan, tetapi penting untuk meningkatkan kemampuan merencanakan perubahan titik perawat pada semua tingkatan posisi klinis harus memiliki kemampuan menyelesaikan masalah dan mengambil keputusan yang efektif, baik sebagai pelaksana atau staf maupun sebagai pemimpin.Berpikir kritis sangat berkaitan dengan kemampuan ketepatan penilaian klinis, pengambilan keputusan, mengambil tindakan, mendeteksi komplikasi serta memiliki inisiatif untuk memecahkan masalah.

\section{BERPIKIR KRITIS}

\section{a. Definisi Berpikir Kritis}

Berpikir kritis menurut Gunawan 2003 berpikir kritis adalah suatu kemampuan untuk berpikir dengan secara kompleks yang menggunakan proses diantaranya analisis serta evaluasi. Berpikir kritis melibatkan keahlian berpikir induktif atau mengenai permasalahan yang memiliki sifat terbuka, mengenali hubungan, mampu untuk menemukan sebab serta akibat, membuat kesimpulan dengan data yang relevan. Selain keahlian berpikir induktif terdapat keahlian berpikir deduktif yaitu kemampuan memecahkan masalah spasial, mampu untuk membedakan antara fakta serta opini.

Walaupun berpikir kritis dijelaskan dalam berbagai definisi, namun berpikir kritis lebih banyak digambarkan sebagai suatu proses daripada sebagai suatu tujuan. Istilah berpikir kritis atau critical thinking berasal dari bahasa Yunani kuno. Paul, Elder dan Bartell berpendapat bahwa kata critical berasal dari dua katakriticos yang berarti penilaian perbedaan dan kriterion berarti standar. Secara etimologis, kedua kata ini menyiratkan makna perkembangan penilaian perbedaan pada standar-standar (Chabeli,2007).Berpikir kritis 
adalah istilah yang digunakan untuk menjelaskan suatu proses kognitif yang mengarahkan pemecahan masalah dan pengambilan keputusan, di mana merupakan proses perbaikan dari pikiran yang mengubah metode proses berpikir untuk meyakinkan bahwa kesimpulan yang diambil telah tepat, beralasan dan teliti (Black \& Hawk, 2009).

Perawat harus mampu membedakan mana fakta dan mana manfaatkan sehingga keputusan yang dibuat sistematis dan logis untuk memecahkan masalah. Kemampuan perawat untuk menjelaskan persamaan dan perbedaan dari informasi yang tidak relevan, juga akan membantu perawat fokus pada situasi yang sedang dihadapinya pada saat ini.

\section{b. Sikap Berpikir Kritis}

Seseorang yang berpikir kritis akan memiliki sikap-sikap berikut ini (Paul, 1998 dalam Christensen Kenney, 2009) :

\section{IntellectualHumanity}

Yaitu suatu kesadaran terhadap keterbatasan pengetahuan diri dan kepekaan diri terhadap kemungkinan prasangka dan bias. Perawat dan tenaga kesehatan sebaiknya tidak mengklaim bahwa mereka mengetahui lebih banyak dari apa yang sebenarnya mereka ketahui.

\section{IntellectualCourage}

Yaitu keinginan dan keterbukaan untuk mendengar secara jujur mengkaji ide-ide orang lain, meskipun perawat sangat berlawanan dengan ide tersebut. Membutuhkan keberanian untuk mempertimbangkan dan mengkaji sudut pandang orang lain dan dengan jujur menimbang kekuatan dan kelemahan pendapat diri.

3. IntellectualEmphaty

Yaitu kemampuan untuk membayangkan diri sendiri di posisi orang lain sehingga dapat memahami pandangan dan jalur penalaran orang tersebut.

\section{IntellectualIntegrity}

Yaitu keinginan menerapkan standar bukti intelektual yang baku dan sama terhadap pengetahuan yang kita milikidan diterapkan terhadap Pengetahuan yang dimiliki oleh orang lain. Hal ini membutuhkan kejujuran untuk menelaah dan mengakui kesalahan atau ketidakkonsistenan pikiran, penilaian dan tindakan diri.

\section{IntellectualPerseverence}


Keinginan untuk mencari wawasan dan kebenaran meskipun sulit dan frustasi. Banyak waktu dan energi yang mungkin dibutuhkan untuk mendapatkan dan mempertimbangkan informasi baru dalam bentuk wawasan baru.

\section{Faith in Reason}

Yaitu percaya pada diri sendiri dan keinginan untuk mencari pikiran rasional dan percaya bahwa orang lain juga mampu melakukan hal yang sama.

\section{IntellectualSenseofJustice}

Yaitu keinginan untuk menelaah sudut pandang orang lain dengan standar internet Tua yaitu keinginan untuk menelaah sudut pandang orang lain dengan standar intelektual yangsama, dan tidak dipengaruhi oleh kepentingan diri sendiri ataupun orang lain.

\section{c. PROSES BERPIKIR KRITIS}

Berpikir kritis membutuhkan proses intelektual aktif yang esensial dalam pengumpulan data, pengambilan keputusan, penyusunan prioritas penyelesaian masalah dan perencanaan asuhan keperawatan. Berikut adalah proses tersebut:

1. Berpikir rasional, logis dan beralasan

Berpikir rasional, logis dan beralasan didasarkan pada pembuatan hubungan antara bukti solid, observasi dan fakta untuk menarik kesimpulan, bukan pengambilan keputusan yang berdasarkan ketidaktahuan, kesukaan, prasangka atau kepentingan sendiri.

\section{Berpikir reflektif}

Berpikir reflektif meluangkan waktu untuk meneliti dan menganalisis data secara akurat mengidentifikasi masalah pasien dan hasil akhir kesehatan yang diinginkan. Kemungkinan tindakan untuk mencapai hasil tersebut dipertimbangkan dan dibandingkan dengan keuntungan, bahaya, dan kerugian dari setiap tindakan tersebut. Perawat tidak hanya sekedar mengambil kesimpulan, tetapi juga menimbang informasi dengan cara yang sesuai dengan disiplin yang dianut.

3. Berpikir otonomi

Berpikir otonomi adalah berpikir dengan diri sendiri tidak hanya menerima atau mendapat manipulasi oleh pandangan orang lain. Pemikir otonomi menganalisis informasi dan memutuskan apa yang paling benar dan terpercaya. 


\section{Berpikir kreatif}

Berpikir kreatif ini bertujuan dan mengarah pada tujuan guna menghubungkan atau mensintesis informasi sehingga terlibat dengan cara baru atau memberi konklusi yang unik. Berpikir kreatif adalah kemampuan untuk membina hubungan, mentransfer informasi ke dalam situasi baru, merancang pilihan alternatif, dan mendapatkan atau menemukan penyelesaian baru terhadap suatu masalah.

5. Memutuskan konklusi dan tindakan

Memutuskan konklusi dan tindakan mencakup menganalisis dan mengevaluasi buktibukti, membandingkan pilihan, menimbang kerugian, risiko dan keuntungan serta memperkirakan keberhasilan pencapaian hasil akhir yang diinginkan.

\section{PENGAMBILAN KEPUTUSAN}

Pengambilan keputusan dapat dianggap sebagai suatu hasil atau keluaran dari proses mental atau kognitif yang membawa pada pemilihan suatu jalur tindakan diantara beberapa alternatif yang tersedia. Menurut Sondang P Siagian pengambilan keputusan adalah suatu pendekatan yang sistematis terhadap hakikat alternatif yang dihadapi dan mengambil tindakan yang menurut perhitungan merupakan tindakan yang paling cepat. Jadi dapat disimpulkan bahwa pengambilan keputusan adalah proses berpikir untuk memilih tindakan terbaik guna mencapai tujuan yang diharapkan. Keputusan harus dibuat kapanpun terdapat pilihan eksklusif bersama atau saat terdapat pilihan untuk melakukan tindakan atau tidak.

Ada lima hal yang perlu diperhatikan dalam pengambilan keputusan:

1. Proses pengambilan keputusan tidak terjadi secara kebetulan.

2. Pengambilan keputusan tidak dilakukan secara asal-asalan tapi harus berdasarkan pada sistematika, yaitu :

a. Tersedianya sumber-sumber untuk melaksanakan keputusan yang akan diambil.

b. Kualifikasi tenaga kerja yang tersedia.

c. Falsafah yang dianut organisasi.

d. Situasi lingkungan internal dan eksternal yang akan mempengaruhi administrasi dan manajemen di dalam organisasi.

3. Masalah harus diketahui dengan jelas. 
4. Pemecahan masalah harus didasarkan pada fakta-fakta yang terkumpul dengan sistematis.

5. Keputusan yang baik adalah keputusan yang telah dipilih dari berbagai alternatif yang telah dianalisis secara matang.

Apabila pengambilan keputusan tidak didasarkan pada kelima hal diatas maka akan menimbulkan berbagai masalah seperti:

1. Tidak tepatnya keputusan.

2. Tidak terlaksananya keputusan karena tidak sesuai dengan kemampuan organisasi baik dari segi manusia, uang maupun material.

3. Ketidakmampuan pelaksana untuk bekerja karena tidak ada sinkronisasi antara kepentingan organisasi dengan orang-orang di dalam organisasi tersebut.

4. Timbulnya penolakan terhadap keputusan.

Adapun langkah-langkah dalam proses pengambilan keputusan yaitu:

a. Identifikasi tujuan, perawat dapat mengidentifikasi Mengapa keputusan perlu diambil dan apa kebutuhan yang perlu ditentukan.

b. Tetapkan kriteria, ketika perawat menetapkan kriteria pengambilan keputusan, ada 3 pertanyaan harus terjawab: Apa hasil yang diharapkan, Apa yang perlu dipertahankan, dan apa yang perlu hindari.

c. Timbang kriteria, pada tahap ini pengambilan keputusan menetapkan prioritas atau mengurutkan aktivitas tas-tas atau layanan dengan urutan kepentingan dari yang kurang penting sampai yang penting saat dihubungkan dengan situasi khusus. Menimbang sifatnya adalah khusus terhadap situasi, aktivitas dapat diurutkan sebagai yang paling penting pada situasi dan yang tidak penting pada situasi yang lain.

d. Cari alternatif, pengambilan keputusan mengidentifikasi semua cara yang mungkin dilakukan untuk memenuhi kriteria tersebut. Pada situasi klinis, alternatif yang dapat dipilih dari kisaran intervensi keperawatan atau strategis perawatan klien.

e. Tadi alternatif, perawat menganalisis alternatif untuk memastikan bahwa ada penjelasan rasional objektif terkait kriteria yang ditetapkan untuk memilih satu strategi yang lain.

f. Proyeksikan, perawat memakai pemikiran kreatif dan skeptisisme untuk menentukan konsekuensi negatif yang mungkin terjadi sebagai hasil keputusan dan menyusun rencana untuk mencegah, meminimalkan dan mengatasi semua masalah. 
g. Implementasikan, rencana keputusan diimplementasikan.

h. Evaluasi hasil, sama seperti asuhan keperawatan, dalam melakukan evaluasi perawat menentukan keefektifan rencana dan menetapkan Apakah tujuan awal telah tercapai.

Proses pengambilan keputusan dan proses keperawatan mempunyai beberapa kesamaan dan perawat menggunakan pengambilan keputusan pada semua langkah proses keperawatan. Adapun perbandingan antara proses keperawatan dan proses pengambilan keputusan yaitu sebagai berikut:

1. Proses Keperawatan: Pengkajian

Proses Pengambilan Keputusan : Mengidentifikasi Tujuan.

2. Proses Kerawatan: Diagnosis

Proses Pengambilan Keputusan:Menetapkan Kriteria, Menimbang Kriteria, Mencari Alternatif, Mengkaji Alternatif, Memproyeksikan.

3. Proses Keperawatan : Mengimplementasikan

Proses Pengambilan Keputusan : Mengimplementasikan.

4. Proses Keperawatan : Mengevaluasi

Proses Pengambilan Keputusan : Mengevaluasi Hasil.

Sikap berpikir kritis dapat ditingkatkan dengan memantapkan secara positif dan motivasi lingkungan kerja. Kreativitas penting untuk membangkitkan motivasi secara individu sehingga mampu memberikan konsep baru dengan pendekatan inovatif dalam memecahkan masalah atau isu secara fleksibel dan bebas berpikir. Keterbukaan menerima kritik akan mengakibatkan hal positif seperti: semakin terjaminnya kemampuan analisa seseorang terhadap fakta dan data yang dihadapi dan akan meningkatkan kemampuan untuk mengatasi kelemahan.

Berpikir merupakan suatu proses yang berjalan secara berkesinambungan mencakup interaksi dari suatu rangkaian pikiran dan persepsi. Sedangkan berpikir kritis merupakan konsep dasar yang terdiri dari konsep berpikir yang berhubungan dengan proses belajar dan kritis itu sendiri sebagai sudut pandang. Manfaat berpikir kritis bagi seorang perawat adalah penerapan profesionalisme, penting dalam membuat keputusan, argumentasi dalam keperawatan, dan penerapan proses keperawatan.

Keputusan dalam penyelesaian masalah adalah kemampuan mendasar bagi praktisi kesehatan khususnya dalam asuhan keperawatan. Tidak hanya berpengaruh pada proses pengelolaan asuhan keperawatan, tetapi penting untuk meningkatkan kemampuan 
merencanakan perubahan. Perawat pada semua tingkatan posisi klinis harus memiliki kemampuan menyelesaikan masalah dan mengambil keputusan yang efektif, baik sebagai pelaksana atau staf maupun sebagai pemimpin.

Berpikir kritis dalam keperawatan merupakan komponen esensial dari akuntanbilitas profesional dan kualitas asuhan keperawatan. Diminta untuk bisa berpikir kritis dengan menggunakan pengetahuan mengenai ilmu keperawatan nya secara menyeluruh agar bisa memberikan perawatan yang efektif (Billings, 2009). Untuk meningkatkan pelayanan kesehatan sangat dibutuhkan tenaga kesehatan seperti dari bidang ilmu keperawatan, dengan pengembangan kemampuan berpikir kritis yang merupakan komponen penting karena perawat selalu dihadapkan dengan situasi yang kompleks yang menuntut penilaian akurat, pengambilan keputusan yang tepat dan merupakan proses pembelajaran yang terus-menerus (Mulyaningsih, 2013).

Perawat memiliki peranan penting dalam mengambil keputusan klinis yangtepat dan akurat. Pengambilan keputusan klinis merupakan hal yang membedakan antara perawat dan staf teknis. Perawat profesional akan mengambil tindakan yang cepat dan tepat ketika keadaan klien memburuk, mendeteksi jika pasien mengalami komplikasi serta memiliki inisiatif untuk mengatasinya. Sehingga menuntut perawat untuk berpikir kritis dan mempunyai waktu tanggap yang cepat. Berpikir kritis memiliki kaitan dalam proses pengambilan keputusan dan penilaian klinis yang akan menjadi penentu pemberian tindakan yang tepat maupun pemberian Asuhan Keperawatan yang profesional.

\section{KESIMPULAN}

Berpikir kritis adalah teknik berpikir yang melatih kemampuan dalam mengevaluasi atau melakukan penilaian secara cermat tentang tepat atau tidaknya atau layak atau tidaknya suatu gagasan yang mencakup penilaian, serta analisa secara rasional tentang semua informasi, masukkan, pendapat dan ide yang ada, kemudian di rumuskanlah kesimpulan dan pengambilan suatu keputusan.

Pengambilan keputusan dalam penyelesaian masalah merupakan kemampuan dasar bagi tenaga kesehatan. Khususnya dalam bidang keperawatan, pengambilan keputusan sangatlah dibutuhkan untuk membuat asuhan keperawatan yang tepat kepada pasien.

Jadi dapat disimpulkan bahwa berpikir kritis sangat erat hubungannya dengan pengambilan keputusan dalam keperawatan. Karena perawat sangat dekat dengan pasien, 
sehingga dalam berbagai keadaan yang dialami pasien, baik ketika pasien keadaannya memburuk, pasien memiliki komplikasi penyakit, perawat harus dapat dengan cepat dan tanggap memberikan asuhan keperawatan yang profesional, sehingga perawat dituntut untuk dapat berpikir kritis dan mempunyai waktu tanggap dan cepat dalam mengambil keputusan untuk pemberian asuhan keperawatan kepada pasien.

\section{DAFTAR PUSTAKA}

1. Anggeria,Elis.,dkk.2018.Hubungan Supervisi Dengan Pelaksanaan Asuhan Keperawatan Di Ruang Rawat Inap Lantai 10 Rumah Sakit Umum Royal Prima Medan Tahun 2017.Jurnal Kesehatan Vol 3 (2):78-97.

2. Budiono. 2016. Modul Bahan Ajar Cetak keperawatan konsep Dasar kkeperawatan. Kebayoran Baru, Jakarta Selatan. 206 - 223.

3. Deniati,Kiki.,dkk.2018.Pengaruh Berfikir Kritis Terhadap Kemampuan Perawat Pelaksana Dalam Melakukan Asuhan Keperawatan di Rumah Sakit Hermina Bekasi Tahun 2016.Jurnal Kesehatan Vol 12 (1): 21-25.

4. Diane L, H. (2018). Leadership and Nursing Care Manajemen, sixth edi.Philadelphia: W.B Saunders Company.

5. E, Rusminingsih.,Purnomo R.T.2019.Faktkr-Faktor yang Mempengaruhi Kemampuan Berfikis Kritis Perawat Dalam Deteksi Dini DBD di Pelayanan Kesehatan Kabupaten Klaten.Jurnal Ilmu Kesehatan Vol 14 (1):79-92.

6. Erianti, Susi. , dkk. 2019. Determinan Pengambilan Keputusan Klinik Keperawatan di RSUD Arifin Achmad Provinsi Riau. Jurnal Kesehatan komunitas Vol 5(3): 227-234.

7. Fitrianingsih,Nur.2015.Hubungan Asuhan Keperawatan Dengan Pengambilan Keputusan Memilih Pelayanan Rawat Inap di RSUD Panembahan Senopati Bantul.Naskah Publikasi.Program Studi Ilmu Keperawatan Sekolah Tinggi Ilmu Kesehatan Aisyiyah Yogyakarta.

8. Maizar,Agil.2017.Gambaran Berpikir Kritis Dalam Problem Based Learning (PBL) Mahasiswa Keperawatan FKIK UIN Syarif Hidayatullah Jakarta.Skripsi.Fakultas Kedokteran dan Ilmu Kesehatan Universitas Islam Negeri Syarif Hidayatullah Jakarta.

9. Mulyaningsih. (2013). Peningkatan Perilaku Caring Melalui Kemampuan Berpikir Kritis Perawat. Jurnal Managemen Keperawatan, 1(2), 100-106.

10. Simamora, R. H. (2019). Menjadi perawat yang: CIH'HUY. Surakarta: Kekata Publisher. 
11. Simamora, R. H. (2005). Hubungan Persepsi Perawat Pelaksana Terhadap Penerapan Fungsi Pengorganisasian Yang Dilakukan Oleh Kepala Ruangan Dengan Kinerjanya Diruang Rawat Inap RSUD Koja Jakarta Utara (Doctoral dissertation, Tesis FIK UI, Tidak dipublikasikan).

12. Sudono,Bambang.,dkk.2017.Gambaran Kemampuan Berpikir Kritis Perawat Primer Dalam Pelaksanaan Asuhan Keperawatan di Rumah Sakit Islam Surakarta.Jurnal Kesehatan Vol 10 (1):79-106. 